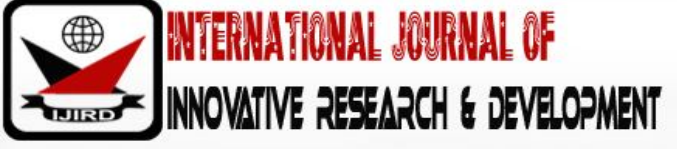

ISSN 2278 - 0211 (Online)

\section{A Critical Analysis of Post-Independence African Leadership in Chinua Achebe's a Man of the People}

\author{
Panaewazibiou Dadja-Tiou \\ Lecturer, Department of English, University of Kara, Togo
}

\begin{abstract}
:
This article purports to critically evaluate the leadership of post-independence African leaders in Achebe's A Man of the People, a leadership characterized by mediocrity, hypocrisy, moral decadence, egoistic tendencies, and corruption. The work also aims to show how Chinua Achebe has used this novel to reflect the socio-political realities of the African continent. Furthermore, the article seeks to demonstrate that post-independence African leaders have deviated from democracy to dictatorship. In the same vein, the paper endeavours to portray the shortcomings of the contemporary African society. This type of ruling led to socio-political and cultural disillusionment on the continent. Instead of contributing to the development of the continent, these leaders rather plunged the continent into extreme poverty. They betrayed their counterparts who fought together with them to accede to independence. They misused their power and enrich themselves at the expense of the masses. The desire for self-realisation and freedom have remained a dream. The analysis of this article will be conducted in the light of post-colonial theory.
\end{abstract}

Keywords: Post-independence, corruption, disillusionment, development, poverty, leadership, leaders

\section{Introduction}

The attainment of independence by most African countries in the sixties aroused in the mind of most Africans a feeling of happiness and hope. Most Africans thought that their conditions were going to shift from poverty to prosperity since the destiny of the continent is now in the hands of their own brothers who promised a better future for the continent. This legitimate aspiration of the masses has been thwarted by these new African leaders who took over from their former white colonisers. This state of things has accurately been portrayed in literary works.

Writers, being part of the society and feeling indebted to it, could not stay aloof. They too, through their works of art, suggest some ways out of the myriad of challenges confronting the entire human race. These writers believe that literature, in its fictiveness, proffers means which, when well employed, could help human society to revisit some social iniquities or injustices that constitute most of the time a heavy stumbling block to its sustainable development. It is to respond to this need of reconstructing African societies that Achebe, faithful to his mission of awareness-raising, wrote this novel, in which he exposes the weaknesses and the sickness of post-colonial African leaders' ruling of the continent. He portrayed his country which is symbolized by the sickness of the leader. Achebe like many African writers of the postcolonial era acknowledges the cardinal role of creative literature when it comes to the matter of human redressing. This is why he wrote A Man of the People, in which he mocked at the leadership of post-independence African rulers. Through the portrayal of the chief M. A. Nanga, one of the major characters from the novel, the writer succeeded in revealing the true nature of post-colonial African leaders. This article purports to evaluate critically the leadership of post-independence African leaders in Achebe's A Man of the People. The work also aims to show how Chinua Achebe has used this novel to reflect the Socio-political realities of the entire African continent. Furthermore, the article seeks to demonstrate how postindependence African leaders have deviated from democracy to dictatorship and to point out the shortcomings of the contemporary African societies.

The only change Africans witnessed was a new form of colonization but now orchestrated their own brothers who took over the destinies of the new nations in hands. It becomes clear that the new elite who took over continued the same system of their former white colonizers. They failed to satisfy the need of their populations whose conditions are still alike. The analysis of this article will be conducted in the light of post-colonial theory.

\section{The Portrayal of Post-Colonial African Leadership in a Man of People}

Most of Chinua Achebe's novels set in sixties such as A Man of the People portray post-independence Africa, where leaders have shifted from the norms of democracy to personal and autocratic rule, Mavis Thokozile Macheka (2014). The fictionalized country depicted in the novel is Nigeria, one of West African countries that can be the representative of the whole Africa. Corruntion. personal cult. violence. the embezzlement of countrv's wealth is what characterize this societv. 
Leaders in this fictionalized Nigeria indulged the country into extreme poverty and this makes of independence worthless and meaningless. The desire of the population to see their leaders introduce in their ruling moral principles and standard norms has been disillusioned and disenchanted. Moral principles have been replaced by personal principles which main purpose is to satisfy their need leaving the whole population aside. The taste for freedom, the fair management in the continent's affairs has remained a dream. Achebe in this novel shows the extent to which post-colonial African leaders have betrayed and deceived the masses' expectations. New leaders who are supposed to work for the benefit of the nation turned to serve their personal and egoistic interests forgetting their brothers and sisters who fought at their sides for independences. African leaders should introduce in their daily management of the continent's affairs the international principles of governance. After the political independence, many African nations, have had in mind that black people promising to improve the living conditions of their fellow citizens. Unfortunately, after only few years' office tenure these post-colonial leaders who took over power from their former white colonial masters started developing many vices such as corruption, mismanagement, nepotism, cronyism, embezzlement of public funds, bribery, and tax harassment, to mention but a few. With the rise of such vices undermining the foundations of Africa's economic, social as well as political growth, committed African writers chose such a set of themes to develop in their fiction. In this wake, Achebe called for a renaissance in the themes of African literature or fiction after the advent of independence in some African countries. Through his novel, A Man of the People, Achebe denounces the bad management and the pathologies of the new African elite in power.

In her study devoted to this novel, Danièle Stewart has it that "Achebe allait droit au but: dénoncer le régime en place, certes mais avec le talent qui convainc. Sa plus grande subtilité allait consister à utiliser des moyens comiques, en particulier la farce, de façon à donner le change.' D. Stewart (1965). The personality of the chief Nanga shows the extent to which the legacy of colonialism is apparent in post-colonial African leaders' management. The portrayal of this character is a way for Achebe to express his total disagreement as far as the ruling of African leaders is concerned. D. Gupta (1993) sees it in the same way when he declares:

Immediately after independence, at a critical juncture of Nigerian history, Achebe felt the need to stand against the "power of events" which had shaped his choice of language by writing a highly critical novel. The bitterness we find in A Man of People is unmistakable an impact of the huge disillusionment that followed the coming of independence in 1960, a glorious year for Nigeria. (P.84)

This point of view shows how Achebe felt the need to fight against the bad ruling of Africa by her own sons. The new leaders who took over from their former masters did not put the interests of the continent in the first place but their aim is how to amass as much as wealth they could for their own use leaving the interests of the population aside. In this vein, they are ready to kill their brothers who may have different vision from theirs. Chief Nanga in this work epitomizes postcolonial leaders who are ready to use every means to achieve their goal. He even uses language as a weapon to persuade his people and by so doing, he is able to acquire prestige and wealth as much as he could. F. Jussawalla (1993) comments Chief Nanga's attitude in the following:

In A Man of the People Achebe shows how using different varieties of the English language becomes a political device and even a persuasive device. Chief Nanga, the "man of the people", finds that speaking to different people with their level or type of usage wins him popularity. (P.170)

This shows the extent to which, African politicians use language to lull the masses. Chief Nanga uses English language to convince his people on his ideals which are contrary to what should be in a country whereby, democratic norms prevail. Aware of his people's ignorance, Chief Nanga is wit and wise and has many arguments to let them accept his manipulative actions. The masses being in poverty are ready to accept anything that Chief offers them. Odili, Nanga's opponent vehemently expresses his deception and disagreement about Nanga's actions. Odili has it that "They were not only ignorant but cynical. Tell them that this man had used his position to enrich himself and they would ask you- as my father did - if you thought that a sensible man would spit out the juicy morsel that good fortune placed in his mouth." (A. Chinua, 1966, p.2). Amply, this passage helps the reader understand the situation in which post-colonial Africans are living as a result of their own brothers' misruling of the continent. Achebe being an awareness-raiser, felt the need to highlight the ongoing situation so as to help his counterparts get out of the undermining situation. To achieve this, Achebe made use of farce, a literary device to enhance the reader's understanding. D. Stewart (1965) is of the same view when she has it that: "Néanmoins, dans chaque cas, la farce a servi de paravent à une réalité beaucoup plus sordide, que ce soit l'assassinat politique présumé d'un profiteur, ou le vol ou la luxure comme mode de vie" (P. 44.) By using this technique, Achebe intends to call for change. Since it is not only used to criticize but also to reform, Achebe's interest in using farce is to explore in depth the socio-political situation of contemporary Africa and to analyse the nature of contemporary leader whose main purpose is to satisfy his personal interests. It is apparent that post-colonial man becomes immoral and ready to undertake whatever he can to gain privilege and prestige. This is noticed when the narrator let us know about the immoral relation between Nanga and Odili's girlfriend. As underlined in the following (D. Stewart, 1965): "Un autre épisode dont tout lecteur se souviendra est celui où Elsie, petite amie du personnage principal, finit dans le lit du chef Nanga." (P.44.) This shows the extent to which new leaders misuse their power to maltreat the powerless. Chief Nanga here is nothing but a sample of new leaders who took over from colonizers. The rights of the masses are violated and neglected at the expense of the power holders.

Through Nanga, Achebe denounces clearly new African elites who have become leaders of the newly independent nations. These elites are involved in many illegal practices which help them amass much wealth and maintain the whole population in a situation of despair, servitude and stagnation. The narrator let us know that Chief Nanga has built many houses with the money of his political party. The money that should be used for the realization of the projects of the country is diverted for Nanga's personal projects. The country is poor but the leaders don't care about this situation. What 
are their concerns are how to satisfy their opportunistic ambitions? Achebe's fictional society is the one which displays different characteristics of poverty, dirtiness, sickness and so forth. The country is at risk and vulnerable to all kinds of sickness. The narrator highlights: "As the local inhabitants said at the time, you could 'hear' the smell of the town ten miles away." (C. Achebe, 1966, p.41). Hearing the smell of the town from ten miles away, gives a picture of a dirty town most of which can be found in post-colonial nations.

Another strategy of these leaders consists in delaying some important actions which will be carried out on the occasion of elections. All this leads innocent people to vote for them based on the actions they are engaged in. As the following passage points out, (Achebe, 1966) "But my host spoke with great feeling, almost annoyance, about a certain road which had to be tarred before the next elections" (P.42). This road mentioned in the extract should have been tarred already but Nanga planned to start the works before election in order to allow the naive people to vote for him. This is recurrent in most post-independence African nations. Daniele Stewart (1965) makes an in-depth portrayal of Nanga in the following:

En dernière analyse, Nanga, démagogue et corrompu, n'est qu'un exemple du vol organisé qui est le thème essentiel du livre. Le vol a lieu à tous les niveaux : c'est une façon d'être, voilà tout. Chacun prend ce qu'il peut quand il le peut, y compris la femme ou le mari de l'autre. En fin de compte, loin d'être un Chef Honorable, Nanga est un Voleur Honorable. (P.56)

His title is just the opposite of what he stands for. As honourable chief, Nanga should normally have been the role model others should follow but his actions are worsening the development of his country. Nanga's attitude epitomizes that of post-colonial African leaders whose actions are the source of underdevelopment of the continent. This undermining situation leads citizens of the different African countries into moral decadence instead of contributing to the development of the continent. Achebe as a morally upright literary critic has shown through his novel that no country can develop economically when politicians and other people in government are corrupt in the highest level. Before this situation, some notions such as development, freedom, prosperity and their likes will only sound as a dream. Achebe signposted the fact that African politicians are indeed very corrupted at the highest level. Therefore, he used, the character of Chief Nanga in this novel to depict the way most African politicians often siphon public funds to enrich themselves at the expense of the majority in the society who are still suffering despite their undeniable efforts in the attainment of independence.

It is also interesting to note how power can be used in literature as an aesthetic device and a socio-political tool designed to bring about awareness and perhaps induce social change. A Man of the People reveals Achebe's disillusionment and disenchantment at what has become of independence in most African countries. Through this novel, Achebe reveals the mess into which his country Nigeria had been put by the new regime of the newly independent leaders whose main intention is to satisfy their personal and egoistic ambition. Achebe portrays a society whose moral fibber is completely eroded and moral decadence is pervasive and consuming. Mohd Ashraf Bhat (2014), viewing the same aspect in his article, observes:

The change of guard did not help in bringing about a change, a change that Africa had longed for. The new indigenous ruling African class involved itself in practices that were not different from earlier colonizers. Corruption, snobbery and other evil practices left the people only disappointed. Sensing this, authors like Ngugi wa [sic]Thiango, Chinua Achebe and Ayi Kwei Armah had to relook at their roles as authors. (P.18)

In portraying this fictional society, the way, he did, Achebe's aim is to raise the awareness of the leaders on the emergency to get rid of this type of leadership and embrace the one which will stimulate democratic capacity. The aim of each leader should be to contribute to the development and the well-being of his compatriots. A true leader should put the interest of the masses at the first place. A leader should be at the service of his people not the other way round one but in post-colonial Africa, leaders expect their people to do them service. As his name stands for, Chief Nanga should be the one who should work for the benefit of his people but this turns to be a threat to them. This is paradox but it becomes normal in the sight of post-colonial leaders who are ready to sacrifice their populations for their interests. Chief Nanga in this perspective is a vivid example. As a leader, his responsibility should be the search for his peoples' welfare but this is not his concerns.

Chief Nanga considers his society as his personal property and thus can use it as it pleases him. It is what makes him openly express the following (Achebe, 1966), "You will lose your deposit and disgrace yourself. I am only giving you this money because I feel that after all many years of service to my people I deserve to be elected unopposed so that my detractors in Bori will know that I have my people solidly behind me." (P.118). Such an expression may instil in the reader's mind a kind of a leader who worked hard for his people but it is just the speech of a corrupt leader. He did nothing for his society but he wanted to be maintained in power. The narrator gives the following account of Chief Nanga as follow (Stewart, 1965):

Chief the Honourable M.A. Nanga, M.P..., a corrupt, uncultured Minister of culture in a corrupt regime in an independent African state. In a country where the majority of the peasants and workers live in shacks and can afford, only pails for excrement, the Minister lives in 'princely seven-bathroom mansion with its seven gleaming, silent action, water-closets (PP.52-53)

Nanga is sure that even if his people refuse to vote for him, he will use other means to win election. This kind of leaders are ready to manipulate their population and prevent other people who have different visions from expressing their point of view. The case in point is Odili who has been granted a scholarship. Granting a scholarship to Odili, Nanga's opponent, is a way to send him away from the country. He said (1966) "Take your money and take your scholarship to go and learn more book; the country needs experts like you. And leave the dirty game of politics to us who know how to play it." (P.119). Achebe reveals this in his novels in order to raise Africans' awareness on the danger undermining postcolonial Africa. In this novel, Achebe sheds light on the subjugated, exploited majority of the African population, and their 
vision of the future after acceding to independence from colonial rule. Max, the unique and good role model character in this novel can be considered as Achebe's voice because he is one of the fictionalised characters who promotes justice, fair play by denouncing all that go against peoples' well-being in the society. The narrator has it that 'Max began by accusing the outgoing Government of all kinds of swindling and corruption. As he gave instance after instance of how some of our leaders who were ash-mouthed paupers five years ago had become near-millionaires under our very eyes" (Achebe, 1966, P.123). This passage sheds light on the mismanagement of post-independence African leaders who, in a very short time, are ready to become rich as quick as they can. Max in this novel is synonymous with the man in Ayi kwei Armah's The Beautyful Ones Are Not Yet Born (1968) who has fought against all that goes against people's welfare. He has been faithful from the beginning till the end by refusing to compromise the moral principles. This novel of Achebe dramatizes and denatures the common fight for independence and the deception of the new leaders. Tierno Monènembo (1979) in the following extract more sheds light on this analysis:

Ce n'étaient que des espoirs ratés! Eux qui auraient dû être la solution, ils ne l'étaient en rien c'était plutôt eux, le problème, à la lumière de la vérité bercés par le miroitement des privilèges, ils se laissent envelopper par la brume de la corruption. Malades de la cécité, ils ne pouvaient regarder ni voir la douleur de l'Afrique. (P.45)

It is to restore this sudden situation created by these wicked leaders that Achebe has decided to write this novel in order to call for change. In an interview with Donatus Nwoga (1972), Achebe explained his goal as a writer:

I think we might be neglecting our proper function if we take anything for granted instead of thinking what exactly is our society, what are its needs, Aspects of Realism in Chinua Achebe's A Man of the People what can I do, what can I contribute; that is what I was trying to get at, and I think we have a very important function ... this is only one of the roles of the writer, as a teacher (Duerden \& Pieterse, 1972, P.7).

Achebe in this passage explicates clearly the role that a writer has to play as far as his contribution of his society is concerned. In this perspective, a leader who fails to work for the benefit of his society can be considered as the enemy of his community. Achebe as a writer succeeds in conveying his message as far as the reconstruction of his society is concerned. He portrayed Chief Nanga in this way so as to lash political leaders in contemporary society in general and Nigerian society in particular. Chief Nanga is somebody who is greedy of power. He is anything but a man of the people. He is a craft politician, very rhetoric and uses this talent not to help his people but to maintain himself in power in order to amass much wealth. This is what Achebe is denouncing through this novel. Achebe has used this novel as a veritable guideline to instil a sense of socio-political transformation in the minds of Africans, a transformation that will help them to envisage the possibilities of a truly authentic development. Backing firmly his stand and his role as an African writer, Achebe as quoted by Vachaspati Dwivedi (2008) in his article entitled 'Aspects of Realism in Chinua Achebe's A Man of the People' says: "I would be quite satisfied if my novels (especially the ones I set in the past) did no more than teach my readers that their past with all its imperfection was not one long night of savagery from which the first European acting on God's behalf delivered them"(P.11). As said earlier, I think Achebe in writing this novel would like his readers to take conscience as far the leadership of post-colonial African rulers is concerned.

Another thing which is terrifying in post-colonial Africa is the ignorance of the masses. At times, these downtrodden people who should normally express their dissatisfaction on the manner their country is ruled, remain aloof and even seem to support these evil leaders in their wicked way. This has been observed by narrator in Achebe novel (1966) in the following:

The people themselves, as we have seen, had become even more cynical than their leaders and were pathetic into the bargain. 'Let them eat', was the people's opinion, 'After all when white men used to do all the eating did we commit suicide? Of course not. And where are the all-powerful white man todays? He came, he ate and went. But we are still around. The important thing is to stay alive (P.144)

The reading of this passage may lead the reader to consider the masses as being in complicity with the leaders. In this circumstance, anyone who may be protesting against the bad ruling of the leaders will be having internal and external conflicts. All this situation could not favour the change advocated by the norms of democracy. To some extent, one can say that populations are complicit and this empowers these wicked leaders to continue their misrule freely. Nepotism is what characterizes post-colonial leaders' ruling. They offer job to their kinsmen not because they deserve but just because they belong to their tribe. A tangible example comes from Odili who was offered a strategic ministerial post by Nanga for belonging to his tribe.

By the way Odili, I think you are wasting your talent here, want you to come to the capital and take up a strategic post in civil service. We should not leave everything to the highlands tribes-our people must press for their own share of the national cake (1966, P.114.)

The above passage gives us more details on the level of nepotism, 'brotherhood', 'sisterhood', 'uncle hood', 'girlfriend hood' and many others. To mean that, everything is done basing on relationship and not with regard to competence. In a nation whereby these aspects are valued, only mediocrity can prevail

\section{Satirical Portrayal of African Leaders of the Post-Colonial Era as a Call for Change}

Each writer has a particular way of writing. Achebe uses satire as a literary device in order to mock at the political leaders. Purposefully, this mockery aims at calling for change in people's way of living and doing. Instead of attacking them directly, Achebe decides, rather to mock at them in order to bring them smoothly to a re-visitation of their wrong ways of doing.

The novel, A Man of the People is generally a satirical attack on the Nigerian society in particular and African society in general. In another angle, one can notice how Achebe uses this novel to expose the ills of the society and to mock 
at post-colonial leaders' follies. Achebe makes his stand against corruption pointedly clear. Most satires heavily depend on humour as a tool to criticize post-colonial African leaders' misuse of power at will.

They deserve to be hanged," shouted Mr. Nanga from the back benches. This interruption was so loud and clear that it appeared later under his own name in the Hansard. Throughout the session he led the pack of back-bench hounds straining their lash to get at their victims. If anyone had cared to sum up Mr. Nanga"s interruptions they would have made a good hour's yelp. Perspiration poured down his face as he sprang up to interrupt or sat back to share in the derisive laughter of the hungry hyena (Achebe, 1966, P.5.)

Ironically, this was a speech Nanga used to win the Prime minister. Under normal circumstances, Nanga should be the one to be hanged due to his wrong behaviour but he is the one who asks other to be hanged innocently. Another example comes from Odili Samalu's personality who in fact is hypocrite but behaves like an idealistic. He is portrayed ironically as a role model but he isn't. He seems to criticize Chief Nanga but paradoxically he admires his political activities. Many a time, he shows his disapproval for Nanga's attitude but he does nothing to bring some changes. Shatto Arthur Gakwandi (1979) sees it in the same way when he has it that: "Odili himself, the man who judges others, is the most hypocritical. Although he has moral objections to Nanga's political conduct he finds himself shouting 'Hear! Hear!' to the latter's specious remarks at Anata Grammar school." (P.80). This shows how Odili has a double face. He epitomizes most Africans who seem to protest against post-colonial leaders' ruling but once they accede to power, they become worse. Odili who was accusing Nanga to constitute an obstacle to the development of their society did not hesitate to accept his invitation to spend his holidays with him in the capital town, Bori.

Ironically, Odili never rejects Nanga's invitation, nor does he reject the possible gain from such an invitation: a job in the civil service or even a scholarship to study abroad. Such vacillation and political timidity as we perceive in the character of Odili not only highlight the ironic nature of his personality, but even cast on his credibility when he later resolves to enter politics. (Udumukwu, 2016, P.54)

This behaviour of Odili shows how Achebe portrays ironically his characters so as to call for repentance. It is not possible to dislike and love something at the same. This attitude epitomizes the attitude of post-colonial leaders who contradict themselves always because of their lack of sincerity. Achebe in his attempt to call people for change uses comical means as a literary device which could help him convey his message. Chief Nanga and Odili Samalu are the same and join Koomson, a character in Ayi Kwei Armah's The Beautyful Ones Are Not Yet Born. The latter was a minister, the most powerful person in the then Ghanaian society, a society characterized by misrule, poverty and immorality. Ironically, he was obliged to pass through the lavatory hole. It was the sole and unique opportunity he could seize in order to escape death. Depicting him as the way Armah did opens the reader's mind on the author's invitation for his readers to get rid of such dirty behaviour. Eustace Palmer (1994) observes:

And yet, although we are aware of the extent of Koomson's corruption and his spiritual rottenness, we do feel some sympathy for him as he cringes like a frightened animal, and finally squeezes his enormous bulk through the lavatory hole used by the night soil man. The gruelling struggle through the putrid lavatory has two functions. In the first place it enables Koomson to experience the conditions. In the first life of ordinary men and women - the men and women whose trust he has betrayed; but also, the lavatory is really the place where Koomson belongs in the end; its putrefaction mirrors his spiritual rottenness. (P.141)

Koomson and Chief Nanga are the same by their vision and behaviour and respectively, they are being ironic. In doing so, their respective writers would like to invite other people to draw moral lesson from their behaviours. The writers, including Achebe, depict the problems of neo-colonialism in their various texts. They show their disenchantment to the present landscape and socio-political structures of their nations. Achebe asserts bitterly that the collective joy of the events of post-independence disillusionment in which the whole continent at different times seemed to be swept up as an enormous celebration has been a nightmare and betrayal by post-colonial leaders.

\section{Conclusion}

Chinua Achebe agrees and shows that independence and decolonisation did not succeed in bringing the true and authentic freedom and autonomy. The real desires and yearnings of the whole population continued to be sounded as dream. The legacy of colonisation and slavery still has its effects on Africans orchestrated by the new African leaders who took over from their former white masters. The desires of self-development and expression are far from being fulfilled because of the misrule of post-colonial African leaders. After a thoroughly analysis of the ruling of post-colonial leaders, it is noticed that these leaders' main purpose is to satisfy their personal and egoistic ambitions leaving the population in deception. Independence becomes meaningless and useless because the expectations of the poor populations remained unsatisfied. This situation brings disillusionment and despair. All the promises made by African leaders before independence have been unfulfilled. They betrayed the poor populations who fought together with them in order to obtain independence. The desires of shared power and equal distribution of the continent's riches are far from being accomplished. Our analysis also shows that post-colonial African leaders struggle and allocate all social and material amenities and close all doors to others. Their target is to amass all the riches of the continent and leave the poor population in the extreme poverty, a situation which could not allow these downtrodden to claim their ultimate rights. In one word, as a solution for this bitter problem on the continent, I think for the African people to make any meaningful development, they have to be healed from the current postcolonial indisposition. 


\section{References}

i. Stewart, D. (1988). Le roman africain anglophone depuis 1965. D'Achebe à Soyinka, l'harmattan: Paris.

ii. Dhruba, G. (1993). 'Authorial Ideology and Narrative Technique in A Man of the People'. In Bernth Lindfors and Bala Kothan daraman, ed. South Asian Responses to Chinua Achebe New Delhi: Prestige Books International.

iii. Palmer, E. (1994). An Introduction to the African Novel, London: Heinemann Books Ltd.

iv. Feroza, J. (1993). Achebe across Cultural Context. In Bernth Lindfors and Bala Kothandaraman, ed. South Asian Responses to Chinua Achebe, New Delhi: Prestige books International.

v. Kammampoal, B. (2013). The Transformative Vision of Modern Society in Wole Soyinka's TheTrials of Brother Jero. International Journal of Education and Research, vol. 1.

vi. Ashraf, M. (2014). 'Satire in Post-Independence African Novel: A Study of Chinua Achebe's A Man of the People and Ngugi wa Thiongo's Wizard of the Crow, International Journal on Studies in English Language and Literature (IJSELL). Volume 2, Issue 6.

vii. Onyemaechi, U. (2016). 'Ideology and the Dialectics of Action: Achebe and Iyayi' In www.elibrary.state, USA.

viii. Stewart, D. (1988). Le roman africain anglophone depuis 1965 D’Achebe à Soyinka. Paris: L'Harmattan.

ix. Monènembo, T. (1979). Les crapeau-brousse, Seuil.

x. Vachaspati, D. (2008). Aspects of Realism in Chinua Achebe's A Man of the People, African Study Monographs, 29(1): 1-13. 